\title{
SURFACE QUALITY OF PERUVIAN AMAZON WOODS SUBMITTED FOR PLANNING AND SANDING
}

\author{
Miguel Meléndez Cárdenas ${ }^{1}$, Claudio Gumane Francisco Juízo ${ }^{1 *}$, Neptalí Bustamante Guillén², Hector Enrique \\ Gonzáles Mora ${ }^{3}$, Ricardo Jorge Klitzke ${ }^{4}$, Márcio Pereira da Rocha ${ }^{4}$ \\ ${ }^{1}$ Forestry Eng, M. Sc., Universidad Nacional Agraria La Molina, Forest Industries Academic Department, mmecd@lamolina.edu.pe \\ ${ }^{1}$ Forestry Eng., M.Sc. in Forestry Engineering, PPGEF/UFPR, Curitiba, PR, Brazil - *c.gumane@gmail.com \\ ${ }^{2}$ Forestry Eng, Universidad Nacional Agraria La Molina, Forest Industries Academic Department, nbustamante@lamolina.edu.pe \\ ${ }^{3}$ Forestry Eng, PhD, Universidad Nacional Agraria La Molina, Forest Industries Academic Department, egonzales@lamolina.edu.pe \\ ${ }^{4}$ Forestry Eng., Dr., Forest Engineering and Technology Department, UFPR, Curitiba, PR, Brazil - rklitzke@ufpr.br; mprocha01@gmail.com
}

Received for publication: 25/01/2018 - Accepted for publication: 12/02/2019

\begin{abstract}
Resumo
Qualidade de superficie de madeiras amazônicas peruanas submetidas a aplainamento e lixamento. O presente estudo teve o objetivo de avaliar a qualidade da superfície usinada da madeira de espécies amazônicas do Peru, em condições de processamento industrial. Para o mesmo, foram obtidas pranchas de madeira de capirona (Calycophyllum spruceanum), cachimbo (Cariniana domestica) e copaíba (Copaifera paupera), das quais foram retirados e selecionados quatro corpos-de-prova de cada espécie. Os corpos de prova foram previamente acondicionados e submetidos posteriormente a operações de aplainamento e lixamento, considerando três orientações de corte (tangencial, radial e intermediário). Em seguida, avaliou-se a qualidade das superfícies aplainadas e lixadas das espécies estudadas, através da medição da rugosidade superficial (Ra) por meio de um rugosímetro digital de detecção por agulha. Os resultados obtidos indicaram diferenças significativas na qualidade de superfície da madeira entre as espécies nos três planos de corte avaliados, sendo que o plano radial da capirona teve melhor qualidade no aplainamento e lixamento. Concomitantemente, em função das operações realizadas, a madeira de capirona permitiu maior possibilidade para melhor acabamento, seguida da madeira de cachimbo e copaíba, sendo agrupadas assim na $1^{\mathrm{a}}, 2^{\mathrm{a}}$ e $3^{\mathrm{a}}$ classes de qualidade de superfície, respectivamente. Palavras-chaves: Rugosidade superficial, plano de corte, classe de qualidade.
\end{abstract}

\section{Abstract}

The present study aimed to evaluate the quality of the machined surface of wood of Peruvian Amazonian species under industrial processing conditions. For this, planks of capirona (Calycophyllum spruceanum), cachimbo (Cariniana domestica) and copaíba (Copaifera paupera) were obtained from which four specimens of each species were removed and selected. The specimens were previously conditioned and subsequently submitted to planing and sanding operations, considering three cutting orientations (tangential, radial and intermediate). Then, the quality of the flattened and sanded surfaces of the studied species was evaluated by measuring the surface roughness $\left(\mathrm{R}_{\mathrm{a}}\right)$ by means of a digital needle detection roughness meter. The results indicated significant differences in wood surface quality among the species in the three evaluated cutting planes, and the capirona radial plane had better planing and sanding quality. Concomitantly, due to the operations performed, the capirona wood allowed a greater possibility for better finishing, followed by cachimbo and copaíba wood, thus being grouped in the $1^{\text {st }}, 2^{\text {nd }}$, and $3^{\text {rd }}$ surface quality classes, respectively.

Keywords: Surface roughness, cutting plane, quality class.

\section{INTRODUCTION}

One of the key factors to consider for introducing new species to the market is the machining operations used during the finishing step aiming at a surface quality of wood products. For Tiryaki et al. (2015) Wood products are obtained after various machining processes at different stages of manufacturing and the planning of these operations is among the most important in the manufacturing process and obtaining higher value-added wood products. Well, according to Palermo et al. (2014). The quality required by the wood surface is defined by the specific requirements related to the end use of a product, thus influencing its commercial value.

Knowledge of wood properties and the establishment of criteria related to machining operations must be considered, and it is important and advisable to apply procedures that improve surface quality, and enable product economics during surface finishing in the manufacture of elaborate or semi-elaborated as is the case of furniture (SILVA et al., 2009; DIAS JUNIOR et al., 2013).

For Aguilera and Muñoz (2011), the use of improper machining processes can result in a poor surface quality of the wood, due to the presence of raised fibers and pronounced undulations. 
The ripples that appear on the wood surface are usually related to knocks or marks due to the action of knives per inch or millimeter, constituted by the succession of ridges and depressions, which vary in their spacing with advancing speed and speed of cutting (SILVA et al., 2016; MARTINS et al., 2013). Therefore, as the rate of advance of the wood increases the advance per tooth increases and consequently the appearance of the defect. Similarly, increasing the depth of cut increases the surface roughness and roughness and the work loses quality (AGUILERA and MUÑOZ, 2011; LU, 2008).

It is worth remembering that the wood hardly presents a smooth surface as a result of the action of the machinery, as ripples occur due to vibration and movement during the process (VIGNOTE and MARTÍNEZ, 2006). In addition the quality of the wood surface may be influenced not only by the type of tool, but also by the cutting angles, degree of sharpening, cutting speed, feed speed and depth of cut (LU, 2008; AGUILERA and MUÑOZ, 2011).

In this context, the production of higher value-added products must be achieved through various operations with cutting tools that generate imperfections at short intervals on the wood surface in an attempt to reduce surface roughness. In addition, in wood manufacturing, prior planing and sanding operations improve the quality of the workpiece, reducing surface roughness for a good wood finish. (LAINA et al. 2017; MARTINS et al. 2013)

Nevertheless, Emary (1992) emphasizes planing and sanding to eliminate imperfections left in milling and crimping, which usually produce grain pull defects, villi, and rhythmic wave-like knife marks on the wood surface application of paints, lacquers and other finishing materials. Therefore Emary (1992) recommends flattening and sanding to obtain smoother surfaces, since they are operations that generate less and less deep knocks and marks. For Vignote and Martínez (2006) the search to soften the wood surface facilitates the correction with masses and resins further improving the quality of product finish.

On the other hand, Miao and $\mathrm{Li}$ (2014) point out that planing and sanding will influence the surface quality of wood products and that both will be influenced by many factors such as wood properties, sanding particle size, sanding pressure and direction. (LAINA et al., 2017).

This demonstrates that in addition to the process parameters, the surface roughness of the machined wood products will also depend on the anatomical structure of the species, as they contain cell cavities that are independent of any machining process (LAINA et al., 2017). Such characteristics affect the manufacturing processes, mainly in the finishing quality, bonding quality, besides the resistance characteristics (KILIC et al., 2006).

For Aguilera and Muñoz (2011) and Laina et al. (2017) the wood density, texture and anatomical structure are the main characteristics that affect wood roughness. For Coelho et al. (2008), sanding is the operation that makes the wood surface more homogeneous, reducing the influence of the anatomical structure on the roughness profile, allowing the surface to better absorb the finishing materials.

Several studies on the surface profile and roughness of machined wood have been performed aiming at the use of several species in different sectors of the timber industry. According (Martins et al., 2011; Laina et al., 2017), the evaluation of the wood roughness allows to obtain a graphic representation of the surface as this is a simple value that will reveal the quality of the piece, on which its destination and use.

Aiming to evaluate the wood quality this research aimed to measure the average roughness (Ra) of the board surface of three wood species from the Peruvian Amazon in the senses; radial, tangential and intermediate, after planing and sanding operations under industrial processing conditions.

\section{MATERIAL AND METHODS}

\section{Sample Preparation}

For the purpose of this study we used woods from three native species from Peru, from a humid tropical primary forest, named cachimbo (Cariniana domestica), capirona (Calycophyllum spruceanum) and copaíba (Copaifera paupera), supplied by the Department of Ucayali-Peru. Table 1 presents the main characteristics to be considered in the evaluation of wood roughness of the three species.

Table 1. Main characteristics of the cachimbo, capirona and copaíba woods.

Tabela 1. Características principais das madeiras de cachimbo, capirona e copaíba. 


\begin{tabular}{|c|c|c|c|}
\hline \multirow{2}{*}{ Features } & \multicolumn{3}{|c|}{ Species } \\
\hline & Cachimbo & capirona & copaíba \\
\hline Great & Crisscrossed & $\begin{array}{l}\text { Reta e ligeiramente } \\
\text { entrecruzada }\end{array}$ & straight \\
\hline Texture & $\begin{array}{l}\text { Medium and } \\
\text { heterogeneous }\end{array}$ & thin & average \\
\hline $\begin{array}{l}\text { Average diameter of } \\
\text { vases }(\mu \mathrm{m})\end{array}$ & 105 to 236 & 39 a 145 & 144 a 172 \\
\hline Number of pores per $\mathrm{mm}^{2}$ & 2 to 8 & 13 a 25 & 3 a 8 \\
\hline Kind of pores & $\begin{array}{l}\text { Loners and multiple } \\
\text { radials }\end{array}$ & Loners and multiple radials & $\begin{array}{l}\text { Loners and } \\
\text { multiple radials }\end{array}$ \\
\hline Longitudinal parenchyma type & $\begin{array}{l}\text { Reticulated } \\
\text { Apotracheal }\end{array}$ & $\begin{array}{l}\text { Apotracheal } \\
\text { diffuse }\end{array}$ & $\begin{array}{l}\text { Terminal and } \\
\text { vasicentric }\end{array}$ \\
\hline Radius Height $(\mu \mathrm{m})$ & $270-424$ & $144-470$ & $309-691$ \\
\hline Basic density $\left(\mathrm{g} / \mathrm{cm}^{3}\right)$ & 0,59 & 0,76 & 0,61 \\
\hline
\end{tabular}

Source: Acevedo e Kikata (1994)

Four specimens of $20 \times 100 \mathrm{~mm}$ cross section and varying lengths were prepared from each species. The specimens were obtained with sections oriented in (i) tangential (TG), (ii) radial (RD) and (iii) intermediate (IN), which were identified with alphanumeric codes, considering the species, the repeat number and the orientation of the cut.

Then the specimens were submitted to conditioning in a climatic chamber for stabilization of equilibrium humidity around $12 \%( \pm 2 \%)$, and subsequently submitted to planing and sanding tests in an industrial plant, located in Lima, Brazil. Peru.

\section{Planing and sanding}

The planing tests were performed on a SAC RS 63S planer driven with a nominal engine power of 7.4 hp. The cutter diameter was $100 \mathrm{~mm}$ and maximum rotation of $5000 \mathrm{r}$. mn-1. For the tests was established the rotation of $3600 \mathrm{r}$. mn-1. Thus, four knives with an angle of attack of $35^{\circ}$ were used. During the tests, the specimens were flattened at a depth of cut of $2 \mathrm{~mm}$ and a feed rate of $8 \mathrm{~m} \cdot \mathrm{mn}^{-1}$.

For sanding, a pneumatic orbital sander with rotation of 10,000 r.mn ${ }^{-1}$ diameter of the plate and 5" sandpaper holder and simultaneous movement of the circular and elliptical plate were used, using 320-grit sandpaper and aluminum oxide abrasive.

For sanding, a DINABRADE pneumatic orbital sander with a rotation of $10,000 \mathrm{~min}^{-1}$ was used, with a diameter of the plate and 5 "sandpaper holder and simultaneous movement of the circular and elliptical plate, using three grit sizes 80,150 and 320 of aluminum oxide abrasive paper.

\section{Surface Quality Analysis}

Soon after the planing and sanding operations, the surface roughness of the wood was determined $\left(\mathrm{R}_{\mathrm{a}}\right)$

by means of a digital roughness meter MITUTOYO SJ-201P of needle detection is a widely used method to determine the roughness of the wood surface showing good results (SILVA et al., 2016; KILIC et al., 2006).

The roughness was measured considering 56 reading points (4 samples with 14 measurements in each sample) by species and cutting plane, which were systematically distributed according to the specimen lengths, adopting the multi-point sampling system. (Figure 1). Variance analyzes were performed on the planing and sanding (320-grit) operations in the three cutting planes of each of the studied species and a classification was given according to the average radial, tangential and intermediate roughness values of the planed and sanded pieces.

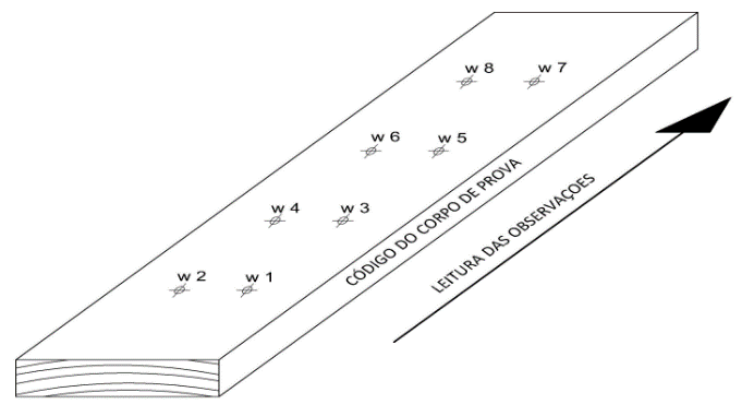

Figure 1. Systematic distribution of roughness reading points in the samples.

Figura 1. Distribuição sistemática dos pontos de leitura da rugosidade nas amostras. 
To complement it, graphs were made with variations in the roughness in the planing and sanding of the three cutting planes of each studied species. A classification was then assigned according to ASTM-D-1666-87 (1999) that regulates the visual qualification of machined wood surfaces, whose principle was to consider the defects generated by the tools on the machined surfaces, as shown in table 2.

Table 2. Quality grades to assign to machined wood surfaces.

Tabela 2. Classes de qualidade a serem atribuídas para superfícies da madeira usinada.

\begin{tabular}{ccc}
\hline Quality class & $\begin{array}{c}\text { Surface characteristics of } \\
\text { machined wood }\end{array}$ & Surface Classification \\
\hline $1^{\mathrm{a}}$ & Surface free of any defects & Excellent (defect free) \\
\hline $2^{\mathrm{a}}$ & Presence of mild to medium shiver & Good \\
\hline $3^{\mathrm{a}}$ & $\begin{array}{c}\text { Presence of strong shiver and slight } \\
\text { pullout of fibers }\end{array}$ & Regular \\
\hline $4^{\mathrm{a}}$ & $\begin{array}{c}\text { Strong shiver and medium to light } \\
\text { yankling of fibers }\end{array}$ & Bad \\
\hline $5^{\mathrm{a}}$ & $\begin{array}{c}\text { Strong pull, regardless of the } \\
\text { presence of shivers }\end{array}$ & Very bad \\
\hline
\end{tabular}

Source: ASTM D 1666-87 (ASTM, 1999).

\section{Statistical analysis}

Statistical analysis of roughness data on planing and sanding was performed with the aid of the Statgraphics XV program. Thus, the normality of the data was verified by the Shapiro-Wilk test, followed by the analysis of variance in a completely randomized design, in a 3x3 factorial arrangement (species x orientation plan), when the null hypothesis was rejected $(\mathrm{P}<0.05)$, the Tukey test was performed to compare means.

\section{RESULTS}

The results of the summary analysis of variance of machining operations in the three cutting planes of the cachimbo, capirona and copaíba species are presented in Table 3.

Table 3. Summary of variance analysis of wood roughness after planing and sanding of the three cutting planes of the species studied.

Tabela 3. Resumo da análise de variância da rugosidade da madeira após o aplainamento e lixamento dos três planos de corte das espécies estudadas.

\begin{tabular}{lll}
\hline Operation & Variation Source & Significance of F \\
\hline \multirow{4}{*}{ Planing } & Species (A) & $13,86^{*}$ \\
& Orientation Plan (B) & $21,05^{*}$ \\
& A x B & $5,98^{*}$ \\
\multirow{3}{*}{ Sanding } & Species (A) & $90,60^{*}$ \\
& Orientation Plan (B) & $6,97^{*}$ \\
& A x B & $8,88^{*}$ \\
\hline
\end{tabular}

$*$ significant at the $5 \%$ probability level $(.01=<\mathrm{p}<.05)$.

\section{Planing}

Table 4 presents the average values of roughness measured in the planing operation in the three cutting planes studied for the cachimbo, capirona and copaíba woods where it can be observed that there was a significant influence of the species and the cutting plane on the surface roughness. 
Table 4. Average roughness values of cachimbo, capirona and copaíba woods, flattened in the radial, tangential and intermediate planes.

Tabela 4. Valores médios de rugosidade das madeiras de cachimbo, capirona e copaíba, aplainadas nos planos radial, tangencial e intermediário.

\begin{tabular}{|c|c|c|c|c|}
\hline \multirow{2}{*}{ Species } & \multicolumn{3}{|c|}{ Roughness by cutting plane $\left(R_{a}\right)$} & \multirow{2}{*}{$\begin{array}{l}\text { Overall } \\
\text { Average }\end{array}$} \\
\hline & RD & TG & IN & \\
\hline Cachimbo & $\begin{array}{l}6,40 \mathrm{Ba} \\
(9,78)\end{array}$ & $\begin{array}{l}8,19 \text { Aa } \\
(10,13)\end{array}$ & $\begin{array}{l}7,70 \mathrm{Aa} \\
(13,37)\end{array}$ & $7,43 \mathrm{a}$ \\
\hline Capirona & $\begin{array}{l}6,67 \mathrm{Aa} \\
(3,29)\end{array}$ & $\begin{array}{l}6,82 \mathrm{Ab} \\
(6,15)\end{array}$ & $\begin{array}{l}6,61 \mathrm{Ab} \\
(6,67)\end{array}$ & $6,70 \mathrm{~b}$ \\
\hline Copaíba & $\begin{array}{l}6,99 \mathrm{Ba} \\
(11,91)\end{array}$ & $\begin{array}{l}8,19 \text { Aa } \\
(8,88)\end{array}$ & $\begin{array}{l}7,14 \mathrm{Ba} \\
(12,44)\end{array}$ & $7,44 \mathrm{a}$ \\
\hline $\begin{array}{l}\text { Overall } \\
\text { Average }\end{array}$ & $6,69 \mathrm{C}$ & $7,73 \mathrm{~A}$ & $7,15 \mathrm{~B}$ & 7,19 \\
\hline
\end{tabular}

Where: $\mathrm{RD}=$ radial orientation; $\mathrm{TG}=$ tangential orientation and $\mathrm{IN}=$ intermediate orientation.

Averages followed by the same lower case letter in the column and the same upper case letter in the row do not differ from each other by the Tukey test at $95 \%$ probability. Uppercase letters are for comparison between planes and lowercase letters for comparison between species.

* Values in parentheses are the coefficients of variation of the means.

The planing of the cachimbo and copaíba wood presented a lower average surface roughness value only in the radial plane in relation to the tangential and intermediate planes. On the other hand, the average roughness values in the studied cutting planes for the capirona wood did not differ with the same surface quality.

\section{Sanding}

The average results of roughness measured in the sanding operation with 320 grit size in the radial, tangential and intermediate planes of the cachimbo, capirona and copaíba woods are presented in Table 5. Where it is observed that there was a significant difference of the cutting plane and the species in the surface roughness after sanding.

Table 5. Average roughness values of cachimbo, capirona and copaíba woods. sanded in the radial, tangential and intermediate planes.

Tabela 5. Valores médios de rugosidade das madeiras de cachimbo, capirona e copaíba. lixadas nos planos radial, tangencial e intermediário.

\begin{tabular}{ccccc}
\hline \multirow{2}{*}{ Species } & \multicolumn{2}{c}{ Roughness by cutting plane } & $\left(\mathbf{R}_{\mathbf{a} \boldsymbol{\mu} \mathbf{m}}\right)$ & \multirow{2}{*}{$\begin{array}{c}\text { Overall } \\
\text { average }\end{array}$} \\
\cline { 2 - 4 } & $\mathbf{R D}$ & $\mathbf{T G}$ & $\mathbf{I N}$ & \\
\hline \multirow{2}{*}{ cachimbo } & $2,68 \mathrm{Ba}$ & $3,76 \mathrm{Aa}$ & $3,85 \mathrm{Aa}$ & $3,43 \mathrm{a}$ \\
& $(17,99)$ & $(16,69)$ & $(25,57)$ & \\
\hline capirona & $2,00 \mathrm{Ab}$ & $1,80 \mathrm{Ac}$ & $2,10 \mathrm{Ac}$ & \multirow{2}{*}{$1,97 \mathrm{c}$} \\
& $(11,07)$ & $(10,28)$ & $(11,26)$ & \\
\hline copaíba & $2,91 \mathrm{Aa}$ & $2,93 \mathrm{Ab}$ & $2,83 \mathrm{Ab}$ & $2,89 \mathrm{~b}$ \\
& $(15,00)$ & $(10,62)$ & $(10,99)$ & \\
\hline Overall average & $2,53 \mathrm{~B}$ & $2,83 \mathrm{~A}$ & $2,93 \mathrm{~A}$ & 2,76 \\
\hline
\end{tabular}

Where: $\mathrm{TG}=$ tangential orientation; $\mathrm{RD}=$ radial orientation and $\mathrm{IN}=$ intermediate orientation.

Averages followed by the same lower case letter in the column and the same upper case letter in the row do not differ statistically from each other by the Tukey test at $95 \%$ probability. Uppercase letters are for comparison between planes and lowercase letters for comparison between species. * Values in parentheses are the coefficients of variation of the averages. 
Capirona wood again showed the best surface quality with a roughness $43 \%$ and $32 \%$ lower than the cachimbo and copaiba woods, respectively.

\section{Species quality class}

In Figure 2, the variation of the wood roughness of the three studied species is illustrated, allowing to infer that the capirona species presents the least variable wood in its behavior against the planing and sanding operations, followed by the copaiba and cachimbo woods.

\section{Planing}

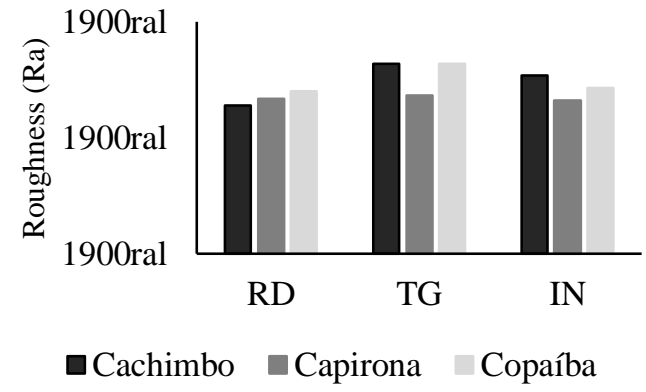

Sanding

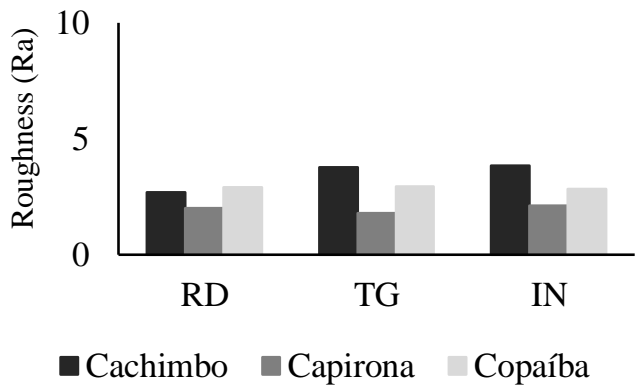

Figure 2. Variation of planing and sanding operations in the three planes of cachimbo, capirona and copaíba woods. Figura 2. Variação das operações de aplainamento e lixamento, nos três planos de corte de madeiras de cachimbo, capirona e copaíba.

Table 6 shows the quality classes assigned to the three species as a function of surface roughness after planing and sanding, according to the visual classification of surfaces performed by ASTM-D-1666-87 (1999).

Table 6. Classification according to the quality of surface roughness of cachimbo species woods capirona copaiba planed and sanded.

Tabela 6. Classificação segundo a qualidade da rugosidade superficial de madeiras das espécies cachimbo capirona copaíba aplainadas e lixadas.

\begin{tabular}{ccc}
\hline Species & Planing & Sanding \\
\hline capirona & $1^{\mathrm{a}}$ class & $1^{\mathrm{a}}$ class \\
copaíba & $2^{\mathrm{a}}$ class & $2^{\mathrm{a}}$ class \\
cachimbo & $3^{\mathrm{a}}$ class & $3^{\mathrm{a}}$ class \\
\hline
\end{tabular}

\section{DISCUSSION}

In Table 3, it was observed that for both planing and sanding, the species, the cutting planes and the interaction between them had an effect on roughness, indicating that there were probably significant differences between the tested treatments, thus proving that Wood surface roughness of the species was influenced by the operations performed, similarly to what was observed by Laina et al. (2017) in the wood of Fagus sylvatica and Quercus alba; Martins et al. (2011) in the wood of Eucalyptus benthamii and Palermo et al. (2014) in the wood of Eucalyptus grandis.

The difference observed in the roughness of flattened and sanded samples in the three species can be explained by the wood properties described in Table 1. Aspects such as fine texture described by Acevedo and Kikata (1994) in capirona wood, give low roughness, in relation to The medium and heterogeneous texture described by the same authors in the cachimbo and copaíba woods contributed to the difference in the surface roughness of the woods.

Another aspect to consider is the difference in wood grain. The intercrossed grain, as a result of the interweaving of the fibers present in the cachimbo wood (Acevedo and Kikata, 1994) seems to have affected the roughness reducing the surface quality. According to Taques and Marques de Arruda (2016), this characteristic directly influences the characteristic of chips obtained during machining operations. Because they generate longer chips, making it difficult to crack the cells by the action of knives or the abrasion of the sanding grain, and 
consequently reducing the quality of the machined surface. Similar results were obtained by Silva et al. (2016), where they concluded in their study that wood with lower grain deviation had lower surface roughness after machining.

The presence of large diameter vessels in the cachimbo and copaiba species contributed to the reduction of wood density and consequently to the reduction of surface quality due to the higher porosity, which corroborates with Vitosyte et al. (2015) according to which the wood surface roughness is also influenced by the wood microstructure, in particular by the cell cavities.

Regarding the influence of density, Aguilera and Muñoz (2011); Dias Junior et al. (2013); Laina et al. (2017); Silva et al. (2016) found an inverse relationship with wood roughness, and the lower the density, the greater the roughness, in line with the results obtained in this study. These factors affected the planing and sanding operations between the species, as they contributed to the ease of pulling out the wood fibers, generating a rougher surface as also observed by Taques and Marques de Arruda (2016); Palermo et al. (2014).

\section{Planing}

For this operation performed in the three species, the capirona wood presented better surface due to its fine texture and relatively high density compared to the other species. In general, the capirona wood had a flattened surface with roughness $10 \%$ smaller than the cachimbo and copaiba woods that had larger roughness probably due to the larger average diameter of the vessels that will influence the medium to coarse texture of the woods besides the lower basic density of the wood. consequently facilitating the removal of fibers with the occurrence of precleavage during the planing action.

In the analysis of the three cutting planes of the three species, it was observed that there was a significant difference between the treatments (Table 4). From the average of the three species, the roughness in the tangential and intermediate planes increased by $15 \%$ and $6 \%$, respectively. Relation to the average roughness observed in the radial plane. Increased tangential roughness in relation to radial plane roughness were also observed by Laina et al. (2017) in the wood of Pinus sylvestris and Quercus alba probably because it has a higher contrast between the early and late wood, which may result in greater roughness in the tangential plane.

According to Martins et al. (2011), planed surfaces are prone to crack generation. Probably due to the action of planer knives, directly in the wood cell cavities, a fact that was evident in this study during the planing of Peruvian woods, and the contrast between the early and late wood were clearly visible mainly in the tangential plane. Nevertheless, these results were inferior to the results found by Martins et al. (2011) during Eucalytpus benthamii planing at 12 years of age, which found an average roughness of $9.08 \mu \mathrm{m}$, possibly due to its higher porosity (15-28 pores per $\left.\mathrm{mm}^{2}\right)$.

In another study Thoma et al. (2015) evaluating the influence of the species on surface roughness also using four flat knives and feedrate that the present study obtained better quality and lower roughness, having determined $4.89 \mu \mathrm{m}, 4.43 \mu \mathrm{m}$ and $5.68 \mu \mathrm{m}$ in the planing of Juglans regia L, Fagus sylvatica and Quercus petraea Liebl respectively, probably due to their higher density and diffuse semi-circular and circular porosities with smaller pores as reported by the authors.

\section{Sanding}

Comparing the wood surfaces, a significant improvement in quality was observed, with an average reduction of $62 \%$ in roughness after sanding.

The tangential plane and the intermediate plane respectively had surfaces with roughness $11 \%$ and $14 \%$ higher after sanding in the three species, following the same trend that occurred after planing. One of the aspects that affected the roughness are the anatomical characteristics of the wood, however, the cachimbo wood was also influenced by the texture due to the crisscrossing grain that suffer the abrasive action (Table 5) of the sandpaper grains during the machining operation. For Aguilera and Muñoz (2011) the presence of these cell types favors the deposition of dust on the wood surface during sanding.

Moura and Hernández (2006) state that in sanding the wood the sanding grains act as small knives on the wood surface producing dust with different exit angles. Similar results were obtained by Hernández and Cool (2008) in which a visual analysis showed, on the sanded surface, the occurrence of raised fibers caused by the abrasive action of sanding. Porankiewicz et al. (2010) state that when sanding different wood species one must consider the parameters of the sandpaper to be used such as the type of material the particle size and the applied pressure. 
The average roughness values obtained in the wood sanding of the three species were similar to those

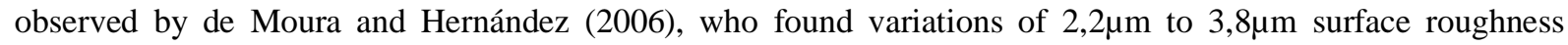
determined in the wood of Acer saccharum. Marsh. on the other hand, Martins et al. (2011) obtained higher roughness values in the sanding of $\mathrm{E}$. benthamii $9,34 \mu \mathrm{m}$.

\section{Species quality class}

In general terms, the capirona species stood out among the other species studied, presenting better behavior in the planing and sanding operations, due to its anatomical structure, straight grain and high basic density that contributed to the lower surface roughness values. In the order of importance, the species copaíba and cachimbo with vessels of large diameters and lower basic density, this therefore presented slightly higher surface roughness values.

This decreasing trend of sanded surface quality in relation to basic wood density is corroborated by the results found by Silva et al. (2009). According to these authors, the lighter woods provided greater feed per tooth resulting in a thicker finish and lower surface quality.

Figure 2 shows that the effect of the cutting plane was indifferent for the capirona wood planing operations, and for sanding the operations performed in the different planes were indifferent for the capirona and copaíba wood, providing similar surface roughness in the three planes. In addition to the porosity and similar grain type among the mentioned species, the action of the machinery may also have influenced the obtaining of chips with the same characteristics in the evaluated planes. Such results were also observed by Laina et al. (2017) in the sanding of the radial and tangential planes of the Quercus alba.

Even so, for the quality classes, it can be observed in Table 6, that the capirona species (1st class) stood out from the others, for presenting such classification according to ASTM-D-1666-87 (1999). Following are the order of importance the species copaíba and cachimbo, which had slightly lower surface roughness values, influenced by the anatomical and physical characteristics of the wood, meeting the results obtained by other authors. (TAQUES e MARQUES de ARRUDA, 2016; PALERMO et al., 2014; DIAS JUNIOR et al., 2013; LAINA et al. 2017; SILVA et al., 2016).

Notwithstanding, the three species presented good quality wood with surface finish, however, even if presented differences between the anatomical structures, the planing and sanding operations under the conditions did not prevent the use of sealants, putties or other finishing products superficial, while obtaining higher valueadded products.

\section{CONCLUSIONS}

From the analysis carried out to evaluate the wood surface quality of three Peruvian Amazonian species, it can be concluded that:

- Capirona wood presented better surface quality and lower range of roughness variation in industrial planing and sanding operations.

- Cachimbo wood presented higher roughness and thus low surface quality with greater variation in industrial planing and sanding operations.

- The tangential plane of the flattened surface generated the lowest roughness for the cachimbo and copaíba woods while the capirona wood showed no difference in surface quality in any cutting plane.

- After sanding, cachimbo wood had better surface quality in the tangential plane, while capirona and copaíba had practically the same quality in all three planes.

- Regarding the classification of surface roughness, the capirona wood presented better surface quality followed by the copaíba and cachimbo species.

\section{ACKNOWLEDGMENTS}

To EXPORTIMO for their support with the supply of wood parts and the machinery used in this research. 


\section{REFERENCES}

ACEVEDO, M; KIKATA, Y. Atlas de Maderas del Perú. Universidad Nacional Agraria La Molina/Universidad de Nagoya. La Molina, Peru. 1994, 202 p.

AGUILERA, A.; MUÑOZ, H. Rugosidad superficial y potencia de corte en el cepillado de Acacia melanoxylon y Sequoia sempervirens. Maderas, Cienc. Tecnol., v.13, n.1, p.19-28, 2011.

AMERICAN SOCIETY FOR TESTING AND MATERIALS. Standard Methods for Conducting Machining Test of Wood and Wood-Base Materials ASTM-D-1666-87. Philadelphia, USA. 1999, 19 p.

COELHO, C.L.; CARVALHO, L.M.H.; MARTINS, J.M.; COSTA, C.A.V.; MASSON, D.; ME`AUSOONE, J. P. Method for evaluating the influence of wood machining conditions on the objective characterization and subjective perception of a finished surface Wood Sci Technol v.42, n.3, p.181-195, 2008.

DIAS JUNIOR, A.F.; SANTOS, P.V.; PACE, J.H. C.; CARVAlHO, A. M.; LATORRACA, J. V. F. de. Caracterização da madeira de quatro espécies florestais para uso em movelaria. Ciência da Madeira (Braz. J. Wood Sci.), Pelotas, v.4, n.1, p. 93-107, 2013.

DE MOURA, L.F.; HERNÁNDEZ, R.E. Effects of abrasive mineral, grit size and feed speed on the quality of sanded surfaces of sugar maple wood. Wood Science and Technology. V.40, n.6, p.517-530. 2006.

EMARY, A. S. Curso de carpintería y ebanistería. v.1. Limusa. México. 1992, 165 p.

HERNÁNDEZ R.E., COOL J. Effects of cutting parameters on surface quality of paper birch wood machined across the grain with two planning techniques. Holz als Roh und Werkstoff; v.66, n.2, p.147-154, 2008.

KILIC, M.; HIZIROGLU, S.; BURDURLU, E. Effect of machining on surface roughness of wood. Building and Environment, v.41, n.8, p.1074-1078, 2006.

LAINA, R.; SANZ-LOBERA, A.; VILlASANTE, A.; LÓPEZ-ESPI, P.; MARTINEZ-ROJAS, J.A.; ALPUENTE, J.; SÁNCHES-MONTERO, R.; VIGNOTE, S. Effect of the anatomical structure, wood properties and machining conditions on surface roughness of wood. Maderas. Ciencia y Tecnología v.19, n.2, p.203-212, 2017.

LU, C. Study on prediction of surface quality in machining process. Journal of Material Processing Technology v.205, n.1-3, p.439-450, 2008.

MARTINS, A.S., FERRAZ, J.M., SANTOS C.M.T., DEL MENEZZI, C.H.S., SOUZA, M.R. Efeito da Usinagem na Rugosidade da Superfície da Madeira de Eucalyptus benthamii. Floresta e Ambiente, Seropédica v.18, n.2, p.135-143,2011.

MARTINS, M.; SILVA, J.R.M.; LIMA, J.T.; GONÇALVES, M.T.T.; FILIPE, A.P. Simulação em uso dos pisos de madeira de Eucalyptus sp. e Corymbia maculata. Cerne, Lavras v.19, n.1, p.151-156, 2013.

MIAO, T.; LI, L. Study on influencing factors of sanding efficiency of abrasive belts in wood materials sanding. WOOD RESEARCH. V.59, n.5, p.835-842, 2014.

PALERMO, G.P.M.; LATORRACA, J.V.F.; MOURA, L.F.; NOLASCO, A.M.; CARVALHO, A.M.; GARCIA, R.A. surface roughness of heat treated Eucalyptus grandis wood. Maderas. Ciencia y tecnologia. V.16, n.1, p.3 $-12,2014$.

PORANKIEWICZ, B., BANSKI, A., WIELOCH, G.: Specific resistance and specific intensity of belt sanding of wood. BioResourrces v.5, n.3, p.1626-1660, 2010.

SILVA, J. R. M.; MARTINS, M.; OLIVEIRA, G. M. V.; BRAGA, P. P. C. Parâmetros de qualidade da usinagem para determinação dos diferentes usos da madeira de Eucalyptus sp. Cerne. Lavras, v.15, n.1, p. 75-83, 2009.

SILVA, F.A.V.; SILVA, R.M.; MOULIN, J.C.; NOBRE, J.R.C.; ANDRADE, A.C.A.; CASTRO, J.P. Qualidade da superfície usinada em pisos de madeira de Corymbia e Eucayptus. Floresta. Curitiba, v.46, n.3, p. 397 - 403 , 2016.

TAQUES, A.C.; MARQUES DE ARRUDA, T.P. Usinagem da madeira de Angelim pedra (Hymenolobium petraeum). Revista de ciências agroambientais Alta floresta, v.14, n.1, p.97-103, 2016. 
TIRYAKI, S.; HAMZAÇEBI, C; MALKOÇOĞLU, A. Evaluation of process parameters for lower surface roughness in wood machining by using Taguchi design methodology. European Journal of Wood and Wood Products. v.73, n4, p537-545, 2015.

THOMA, H.; PERI, L.; LATO, E. Evaluation of wood surface roughness depending on species characteristics. Madera ciencia y tecnología v.17, n.1-2, p.285 - 292, 2015.

VIGNOTE, S; MARTINEZ, I. Tecnología de la madera. Ediciones Mundi-prensa. Madrid, España-Mexico. 2006, $678 \mathrm{p}$.

VITOSYTĖ, J.; UKVALBERGIENĖ, K.; KETURAKIS, G. Roughness of sanded wood surface: an impact of wood species, grain direction and grit size of abrasive material. Materials Science (medžiagotyra). v.21, n. 2.p.255-259, 2015. 